$1-1-2004$

\title{
The pharmacokinetics of nebulized nanocrystal budesonide suspension in healthy volunteers.
}

Walter Kraft

Thomas Jefferson University

Barry Steiger

Sheffield Pharmaceuticals

Don Beussink

Sheffield Pharmaceuticals

John N. Quiring

QST Consultations Ltd.

Nancy Fitzgerald

OST Consultations Ltd.

Follow this and additional works at: https://jdc.jefferson.edu/medfp

Part of the Medical Pharmacology Commons

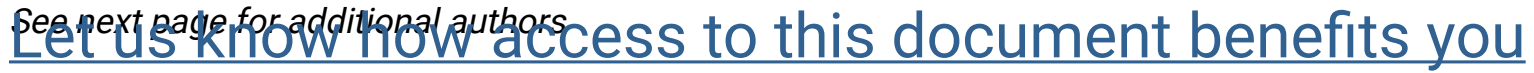

\section{Recommended Citation}

Kraft, Walter; Steiger, Barry; Beussink, Don; Quiring, John N.; Fitzgerald, Nancy; Greenberg, Howard E.; and Waldman, Scott A., "The pharmacokinetics of nebulized nanocrystal budesonide suspension in healthy volunteers." (2004). Department of Medicine Faculty Papers. Paper 197. https://jdc.jefferson.edu/medfp/197

This Article is brought to you for free and open access by the Jefferson Digital Commons. The Jefferson Digital Commons is a service of Thomas Jefferson University's Center for Teaching and Learning (CTL). The Commons is a showcase for Jefferson books and journals, peer-reviewed scholarly publications, unique historical collections from the University archives, and teaching tools. The Jefferson Digital Commons allows researchers and interested readers anywhere in the world to learn about and keep up to date with Jefferson scholarship. This article has been accepted for inclusion in Department of Medicine Faculty Papers by an authorized administrator of the Jefferson Digital Commons. For more information, please contact: JeffersonDigitalCommons@jefferson.edu. 
Authors

Walter Kraft, Barry Steiger, Don Beussink, John N. Quiring, Nancy Fitzgerald, Howard E. Greenberg, and Scott A. Waldman 
The Pharmacokinetics of Nebulized Nanocrystal Budesonide Suspension in Healthy Volunteers

Walter K. Kraft, MD*, Barry Steiger, MD, Don Beussink Pharm D., John N. Quiring, $\mathrm{PhD}$, Nancy Fitzgerald, MS, Howard E. Greenberg, MD, FCP*, Scott A. Waldman, MD, $\mathrm{PhD}, \mathrm{FCP} * \star$

*Division of Clinical Pharmacology,

Departments of Medicine and

^Biochemistry and Molecular Pharmacology,

Thomas Jefferson University, Philadelphia, PA

and

Sheffield Pharmaceuticals,

Rochester, NY (BS, DB)

and

QST Consultations Ltd.

6410 Lake Michigan Dr., Allendale, MI 49401(JQ, NF)

This study was supported by Sheffield Pharmaceuticals, Rochester, NY

Corresponding Author: Walter K. Kraft MD, Division of Clinical Pharmacology, 1170 Main Building, 132 S. $10^{\text {th }}$ St., Philadelphia, PA 19107 walter.kraft@ jefferson.edu (W) 2159559077 (fax) $2159555681(\mathrm{H}) 8565475335$ 


\begin{abstract}
Nanocrystal budesonide (nanobudesonide) is a suspension for nebulization in patients with steroid-responsive pulmonary disease such as asthma. The pharmacokinetics and safety of the product were compared to those of Pulmicort ${ }^{\circledR}$ Respules $^{\mathrm{TM}}$. Sixteen healthy volunteers were administered nanobudesonide 0.5 and $1.0 \mathrm{mg}$, Pulmicort ${ }^{\circledR}$ Respules $^{\mathrm{TM}} 0.5 \mathrm{mg}$ and placebo in a four-way, randomized crossover design. All nebulized formulations were well-tolerated, with no evidence of bronchospasm. Nebulization times were significantly shorter for nanobudesonide compared to Pulmicort ${ }^{\circledR}$ Respules $^{\mathrm{TM}}$. Because of a low oral bioavailability, plasma concentration of budesonide is a good marker of lung-delivered dose. The pharmacokinetics of nanobudesonide 0.5 and $1.0 \mathrm{mg}$ were approximately dose proportional with respect to $\mathrm{Cmax}, \mathrm{AUC}_{(0-\mathrm{t})}$, and $\mathrm{AUC}_{(0 \text {-inf) }}$. Nanobudesonide $0.5 \mathrm{mg}$ and Pulmicort $^{\circledR}$ Respules $^{\mathrm{TM}} 0.5 \mathrm{mg}$ exhibited similar AUC's, suggesting a similar extent of pulmonary absorption. A higher $\mathrm{C}_{\max }$ was noted with nanobudesonide $0.5 \mathrm{mg}$ and the $\mathrm{T}_{\max }$ was significantly different, suggesting a more rapid rate of drug delivery of nanobudesonide 0.5 than Pulmicort $^{\circledR} \quad$ Respules $^{\mathrm{TM}}$. In conclusion, nebulized nanobudesonide $0.5 \mathrm{mg}$ was safe in healthy volunteers, with a similar extent of absorption as Pulmicort Respules.
\end{abstract}


Inhaled anti-inflammatory corticosteroid therapy is an important component of the treatment regimen for chronic asthma. Practice guidelines recommend their use as firstline therapy for all cases of asthma, except mild intermittent asthma ${ }^{1,2 .}$ The use of inhaled steroids early in the course of the disease is associated with improved outcomes compared to treatment with beta 2 adrenergic agonists. ${ }^{3}$ Indeed, the early use of inhaled corticosteroids may alter the natural history of the disease ${ }^{4}$, and possibly reduce the irreversible airway obstruction associated with chronic inflammation of the lungs ${ }^{5}$.

Budesonide is a potent anti-inflammatory corticosteroid with low oral bioavailability. It forms reversible intracellular fatty acid esters in airway and lung tissue, which may prolong lung retention. ${ }^{6}$ Budesonide is available as a dry powder inhaler (DPI) and as Pulmicort ${ }^{\mathrm{R}}$ Respules $^{\mathrm{TM}}$ (AstraZeneca, Wilmington, DE), a suspension for inhalation with a jet-air table-top nebulizer. Pulmicort ${ }^{\circledR}$ Respules $^{\mathrm{TM}}$ is the only corticosteroid suspension for inhalation available in the United States. The DPI form of inhalation therapy is often limited by difficulty with coordination of inspiration, especially in pediatric patients. In addition, the DPI's require adequate inspiratory flow for drug delivery. For these reasons, budesonide delivered by a table-top nebulizer has found increasing use as the best alternative for delivery of corticosteroids to the lungs in children.

Nanobudesonide is a new formulation of budesonide that has been developed for use in a table-top nebulizer. Suspended drug particles (the disperse phase) are in the 75-300 nanometer range in this formulation. This compares to particle size of $\sim 4,400$ nanometer for Pulmicort ${ }^{\circledR}$ Respules ${ }^{\mathrm{TM}}{ }^{7} \quad$ The small crystal size of budesonide in the nanocrystal formulation gives the suspension solution-like characteristics, which may shorten delivery time and improve intrapulmonary distribution compared to the existing preparation. In this 
study, the safety, delivery, and pharmacokinetics of nebulized nanobudesonide were compared to Pulmicort ${ }^{\circledR}$ Respules $^{\mathrm{TM}}$.

\section{METHODS}

\section{Subjects}

Sixteen healthy volunteers (13 males and 3 females) with a mean age of 32.5 (range 2540), mean height of $171.0 \pm 8.4 \mathrm{~cm}$, and mean weight $76.8 \pm 14.5 \mathrm{~kg}$ participated in this study. The study was approved by the Institutional Review Board of Thomas Jefferson University in Philadelphia, PA. All subjects gave written informed consent to participate prior to undergoing any study procedures. No study subject used a topical or systemic corticosteroid, or ingested a cytochrome P4503A inhibitor within 4 weeks of study initiation. Subjects with a history of bronchospasm or a screening FEV1/FVC of $<80 \%$ of predicted were excluded from participation.

\section{Study Design}

This was a randomized, double-blind, four-arm, single-dose cross-over study that compared the pharmacokinetics and safety of nanobudesonide and Pulmicort ${ }^{\circledR}$ Respules $^{\mathrm{TM}}$. The four study arms were (1) placebo, (2) $0.5 \mathrm{mg}$ of Pulmicort ${ }^{\mathrm{R}}$ Respules $^{\mathrm{TM}}$, (3) $0.5 \mathrm{mg}$ of nanobudesonide and (4) $1.0 \mathrm{mg}$ of nanobudesonide. Healthy volunteers were admitted to the Clinical Pharmacology Research Unit of Thomas Jefferson Hospital the day before each treatment. Following an overnight fast, they received one of the four randomized treatments. The study protocol specified that each subject was to receive treatments not less than 5 or more than 10 days apart. 
Spirometry, oximetry, clinical laboratory tests, ECG and vital signs were performed at baseline and at specified intervals. The spirometer was calibrated on a daily basis. Adverse events were monitored throughout the study. Twenty-four hours after each treatment, subjects were reevaluated and discharged from the unit.

\section{Test Drugs and Administration}

Nanobudesonide and placebo were manufactured by Automated Liquid Packaging, (Woodstock, IL) using plastic blow/fill/seal ampules. Packaging and labeling were performed by PCI Services - Clinical Services (Philadelphia, PA). The nanobudesonide placebo consisted of the same ingredients as nanobudesonide without the budesonide. Pulmicort ${ }^{\circledR}$ Respules $^{\mathrm{TM}}$ were purchased from a commercial source. Nebulizers were filled by an unblinded investigational pharmacist. The fill volume for all treatments was $4.0 \mathrm{ml}$. For the $0.5 \mathrm{mg}$ nanobudesonide treatment arm, $2.0 \mathrm{ml}$ of placebo was added to $2.0 \mathrm{ml}$ of active drug.

All treatments were administered by nebulization with a Pari LC Jet nebulizer and a Pari LC Ultra compressor (PARI Respiratory Equipment, Inc., Monterey, CA). A new nebulizer was used for each treatment and each subject had all four treatments administered with the same compressor. Compressors were checked with a calibration nebulizer each day of use. Research personnel reviewed the inhalation procedure with each subject prior to each treatment using a training nebulizer. Subjects were in a sitting position and trained to inhale slowly and steadily through a mouthpiece with a target respiratory rate of 14 to 20 breaths per minute. Nose clips were utilized to avoid inspiration/expiration through the nose. Nebulization was continued until one minute after sputtering was heard. The duration of nebulization and the residual volumes were measured. 


\section{Pharmacokinetics}

Blood was drawn for budesonide levels pre-dose, at 5, 10, 15, 20, 25, 30, 40, and $60 \mathrm{~min}$, and $2,3,4,6,8$, and $24 \mathrm{~h}$ post-dose. Time zero was the beginning of nebulization. Samples were collected in tubes containing sodium heparin, immediately placed on ice, spun at 2200 $\mathrm{g}$ for $10 \mathrm{~min}$.

Analysis of plasma samples was performed by Analytical BioChemistry Laboratories (Columbia, MO) utilizing a validated HPLC-MS/MS method. Using nominal standard concentrations of $60.1 \mathrm{pg} / \mathrm{mL}$ and $802 \mathrm{pg} / \mathrm{mL}$, precision for this assay was $12.9 \%$ and $4.7 \% \mathrm{CV}$ respectively, while accuracy was -8.6 to $-2.8 \% \mathrm{RE}$ of nominal standard concentrations. Plasma was assayed for budesonide in $1.0 \mathrm{ml}$ aliquots. Samples were extracted on a 96-well C-18 SPE plates on a Tomtec Quadra 96® model 320. Desonide

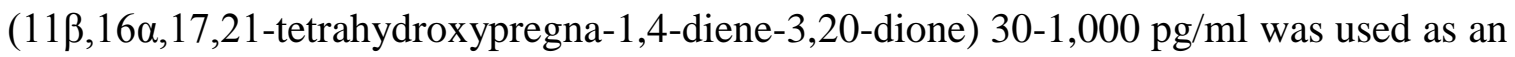
internal standard. During validation, the correlation coefficient (r) was $\geq 0.9976$.

\section{Statistical Analyses}

Statistical analyses were performed using SAS ${ }^{\circledR}$ Version 6.12 (SAS Institute, Cary, NC). Safety variables of FEV1, adverse events and vital signs were analyzed with an analysis of covariance at each time point. Clinical laboratory measurements and oximetry were evaluated in each subject. The pharmacokinetic analyses were performed with SAS using the sorting procedure, PROC GLM, PROC MEANS and G-PLOT. The slope of the terminal phase was used to estimate $\mathrm{AUC}_{(0-\mathrm{inf})}$. Analysis of variance (ANOVA) was performed on untransformed and $\log$ transformed $\mathrm{AUC}$ and $\mathrm{C}_{\max }$ parameters. The model included subject, period, and treatment. For the log transformed analysis adjusted means 
and confidence intervals were calculated for $\mathrm{AUC}(0-\mathrm{t}), \mathrm{AUC}\left({ }_{(0-\mathrm{inf})}\right), \mathrm{T}_{\max }$ and $\mathrm{C}_{\max }$ and backtransformed to the arithmetic scale. For untransformed data, treatments were compared for the $95 \%$ confidence intervals for the difference between means. For transformed data, a 95\% confidence interval was calculated for the ratio of two means. Subjects were evaluated on an intent-to-treat basis, and those receiving at least one dose of the trial medication were included in analyses.

\section{RESULTS}

\section{Demographics}

Sixteen subjects were enrolled and all completed the study. One subject exceeded the maximum ten day window permitted between treatment arm 3 and 4 by four days. This protocol variance did not jeopardize study integrity and this subject was included in the analysis.

\section{Pharmacokinetics}

This study compared the pharmacokinetics of Pulmicort ${ }^{\circledR}$ and nanobudesonide delivered by inhalation (Table 1). Because of the rapid absorption and the limited number of time points during the first $10 \mathrm{~min}$ after the initiation of inhalation, $\mathrm{T}_{\max }$ values obtained are considered estimates. Nevertheless, pairwise comparisons between Pulmicort ${ }^{\circledR}$ Respules $^{\mathrm{TM}}$ and nanobudesonide $0.5 \mathrm{mg}$ revealed significant $\mathrm{T}_{\max }(\mathrm{p}=0.001)$ differences between treatments. Indeed, maximum concentrations were achieved sooner in the nanobudesonide $0.5 \mathrm{mg}$ treatment compared to Pulmicort ${ }^{\circledR}$. In addition, pairwise comparisons of the $\log$ transformed data revealed that the $\mathrm{C}_{\max }$ for nanobudesonide $0.5 \mathrm{mg}$ was significantly $(\mathrm{p}<0.001)$ higher than for a comparable dose of Pulmicort ${ }^{\circledR}$ Respules $^{\mathrm{TM}}$. The extent of 
absorption of Pulmicort ${ }^{\circledR}$ Respules $^{\mathrm{TM}} 0.5 \mathrm{mg}$ and nanobudesonide $0.5 \mathrm{mg}$, estimated by $\mathrm{AUC}_{(0-\mathrm{t})}$ and $\mathrm{AUC}_{(0-\mathrm{inf})}$, was comparable, though formal bioequivalence testing was not performed. The pharmacokinetics of nanobudesonide $0.5 \mathrm{mg}$ and $1.0 \mathrm{mg}$ were approximately dose proportional with respect to $\mathrm{Cmax}, \mathrm{AUC}_{(0-\mathrm{t})}$, and $\mathrm{AUC}_{(0-\mathrm{inf})}$.

\section{Nebulization Times and Residual Volumes}

Nebulization was continued until 1 min after sputtering, which was not detected in one subject receiving Pulmicort ${ }^{\circledR}$ Respules ${ }^{\mathrm{TM}}$ and one receiving $0.5 \mathrm{mg}$ of nanobudesonide (Table 2). The nebulization times for these subjects were 15 and 16 min, respectively. Nebulization times ranged from 4.0 to 16.0 min across all treatments and mean nebulization times were 8.7 min for Pulmicort ${ }^{\circledR}$ Respules ${ }^{\mathrm{TM}}, 7.1 \mathrm{~min}$ for nanobudesonide $0.5 \mathrm{mg}$, and $7.0 \mathrm{~min}$ for nanobudesonide $1.0 \mathrm{mg}$. The mean nebulization time for the subjects receiving Pulmicort ${ }^{\circledR}$ Respules ${ }^{\mathrm{TM}}$ was significantly longer compared to that of the nanobudesonide $0.5 \mathrm{mg}$ group $(\mathrm{p}=0.027)$ and the nanobudesonide $1.0 \mathrm{mg}$ group $(\mathrm{p}=0.029)$. There were 5 , 3 and 2 subjects with nebulization times greater than 10 min in the Pulmicort ${ }^{\circledR}$ Respules $^{\mathrm{TM}}$, nanobudesonide $0.5 \mathrm{mg}$ and nanobudesonide $1.0 \mathrm{mg}$ groups, respectively.

Seven subjects had residual volumes greater than $1.0 \mathrm{ml} ; 4$ in the Pulmicort ${ }^{\circledR}$ Respules $^{\mathrm{TM}}$ group, 2 in the nanobudesonide $0.5 \mathrm{mg}$ group, 1 in the nanobudesonide $1.0 \mathrm{mg}$ group, and one in the placebo group. There was no clear relationship between higher residual volumes and longer nebulization times. Three subjects had residual volumes greater than $1.0 \mathrm{ml}$ in more than one crossover treatment period.

\section{Safety}


There were no significant adverse effects associated with the administration of the test drugs. Four subjects reported a total of 8 adverse events after dosing with placebo. Two subjects reported a total of 4 adverse events (nausea, dizziness, paresthesia, and rhinitis) after dosing with Pulmicort ${ }^{\circledR}$ Respules ${ }^{\mathrm{TM}}$. One adverse event was reported with each of the nanobudesonide groups. These included rhinitis (nanobudesonide $0.5 \mathrm{mg}$ ) and edema at a venipuncture site (nanobudesonide $1.0 \mathrm{mg}$ ). All adverse effects were classified as mild. There was no evidence of bronchospasm in any of the treatment arms. For FEV 1 , the overall treatment effect was not significant at any evaluation ( $\mathrm{p} \geq 0.111)$. In addition, there were no clinically significant abnormalities in measured vital signs, pulse oximetry, electrocardiograms, or clinical laboratory tests.

\section{DISCUSSION}

Inhaled steroids are the preferred anti-inflammatory therapy in the treatment of asthma. Budesonide delivered by nebulization is effective in controlling pediatric asthma, as measured using multiple clinical endpoints..$^{8,9,10,11}$ The efficacy of inhaled budesonide is predominantly mediated by local action, with systemic absorption contributing little, if anything, to the control of inflammation in the lungs. ${ }^{12}$ Budesonide has an excellent safety profile in children. Pediatric patients administered chronic inhaled steroids grow to a normal adult height. ${ }^{13}$ However, safety concerns of a transient, decreased growth velocity in children ${ }^{14}$ have resulted in under-utilization of inhaled corticosteroids in this age group. ${ }^{15}$ The goal of the new nanocrystal formulation budesonide is to maximize efficiency of pulmonary delivery of drug, which may serve to obviate some of these safety concerns.

The delivery of budesonide by nebulization is a complex process that is affected by the characteristics of the nebulizer and compressor, droplet size, properties of the formulation, 
breathing pattern of the patient, and respiratory tree anatomy. A small component of the orally deposited drug may be absorbed through the buccal mucosa. This was minimized in the present study by the use of a mouthwash after nebulization. There is little or no metabolism of budesonide in the lung. ${ }^{16}$ There is extensive hepatic first-pass metabolism of swallowed budesonide, with an oral bioavailability of $\sim 11 \% .{ }^{17}$ Pharmacokinetic evaluation of drug absorption from the lungs, therefore, provides an accurate and reproducible method for comparing the dose delivered to the lung by different inhaler systems or different formulations from the same inhaler system ${ }^{18,19}$ A Medline search for published reports of the pharmacokinetics of budesonide suspension delivered by a tabletop nebulizer yielded a single report from a study in 10 children. ${ }^{20}$ However, neither the budesonide particle size in the suspension nor the manufacturer of the suspension is specified in this European study. Data on file with AstraZeneca reports that in children with asthma, the Pari LC Jet Plus nebulizer with the Pari Master compressor delivered approximately $25 \%$ of labeled budesonide to the patient. ${ }^{21}$ This delivered dose was comparable to that in healthy adults.

In this study of healthy volunteers, the $0.5 \mathrm{mg}$ nanobudesonide and the $0.5 \mathrm{mg}$ Pulmicort ${ }^{\circledR}$ Respules $^{\mathrm{TM}}$ formulations produce a comparable budesonide AUC in plasma, indicating a similar extent of absorption. Because the oral bioavailability of budesonide is relatively low, it is likely that this observation reflects comparable pulmonary deposition for each formulation. The nanobudesonide formulation exhibited approximate linear pharmacokinetics between the 0.5 and $1.0 \mathrm{mg}$ formulations. The nebulization times of nanobudesonide 0.5 and $1.0 \mathrm{mg}$ nanobudesonide were significantly shorter than those 
observed with Pulmicort ${ }^{\circledR}$ Respules $^{\mathrm{TM}}$. There were no significant adverse effects associated with the delivery of the nanobudesonide formulation.

The comparable AUC, higher $\mathrm{C}_{\max }$ and lower $\mathrm{T}_{\max }$ of $0.5 \mathrm{mg}$ nanobudesonide compared to $0.5 \mathrm{mg}$ Pulmicort ${ }^{\circledR}$ Respules $^{\mathrm{TM}}$ suggests more rapid drug delivery, or more rapid absorption. If these differences are due to more rapid absorption, two mechanisms are possible. Nanobudesonide could have more rapid dissolution of the in the airways, or a more distal delivery of drug may facilitate rapid absorption. However, the PK data presented do not allow discrimination between these possibilities. Drug distribution studies will be required to determine the degree and kinetics of pulmonary deposition. While some observations suggest that improved antiinflammatory drug distribution to small airways might result in increased clinical efficacy, ${ }^{22}$ there is no clinical proof that this is the case. ${ }^{23}$ Finally, results reported here in healthy adults should be extrapolated to other populations with caution. Budesonide clearance ${ }^{20}$ and lung deposition ${ }^{19,24}$ differ in pediatric and adult populations. Additionally, drug delivery to the lungs will differ in asthmatic and healthy lungs. ${ }^{25}$ The subjects in this study were not balanced with regard to gender and no subgroup analysis was performed owing to the small number (3) of females participating. However, no gender differences are present in the pharmacokinetic parameters of Pulmicort ${ }^{\circledR}$ Respules $^{\mathrm{TM}} .^{21}$ The potential for differential regional lung delivery of inhaled nanobudesonide based upon gender is unknown. ${ }^{26}$

In conclusion, nanobudesonide exhibited pharmacokinetics that were dose-proportional, and nanobudesonide $0.5 \mathrm{mg}$ yielded budesonide absorption that was comparable to Pulmicort $^{\circledR}$ Respules ${ }^{\mathrm{TM}}$. The higher $\mathrm{C}_{\max }$ and lower $\mathrm{T}_{\max }$ of $0.5 \mathrm{mg}$ nanobudesonide suggests a more rapid rate of either drug delivery or absorption compared to Pulmicort ${ }^{\circledR}$ 
Respules $^{\mathrm{TM}}$. In addition, nanobudesonide administration demonstrated a safety profile that was comparable to Pulmicort ${ }^{\circledR}$ Respules $^{\mathrm{TM}}$. The significantly shorter nebulization time with nanobudesonide compared to Pulmicort ${ }^{\circledR}$ Respules $^{\mathrm{TM}}$ should be advantageous with respect to patient compliance. 


\section{Table 1}

\section{Pharmacokinetics of Pulmicort and Nanobudesonide}

\begin{tabular}{|c|c|c|c|}
\hline & Pulmicort (0.5 mg) & Nanobudesonide (0.5 mg) & Nanobudesonide (1.0 mg) \\
\hline PK Parameter & Mean (95\% CI) & Mean (95\% CI) & Mean (95\% CI) \\
\hline Tmax (min) & $14.4(11.4-18.0)$ & $8.4(5.4-10.8)$ & $11.4(6.0-16.2)$ \\
\hline Cmax (pg/mL) & $662(416-908)$ & $1212(751-1674)$ & $24841236-3733)$ \\
\hline $\begin{array}{c}\text { AUC(0-t) } \\
(\mathrm{pg} \cdot \mathrm{hr} / \mathrm{mL})\end{array}$ & $1518(1071-1966)$ & $1472(1171-1773)$ & $2725(1981-3469)$ \\
\hline $\begin{array}{c}\text { AUC }(0-\mathrm{inf}) \\
(\mathrm{pg} \cdot \mathrm{hr} / \mathrm{mL})\end{array}$ & $1631(1125-2137)$ & $1658(1284-2031)$ & $2893(2118-3668)$ \\
\hline $\begin{array}{c}\mathrm{T} 1 / 2(\mathrm{hr}) \\
\end{array}$ & 5.42 & 6.62 & 5.46 \\
\hline
\end{tabular}


Table 2

Mean Pulmicort and Nanobudesonide Nebulization Times

\begin{tabular}{|l|c|c|c|}
\hline & Duration (min) & SD & Range \\
\hline Placebo & 6.56 & 1.75 & $5-10$ \\
\hline Pulmicort $^{\circledR}$ Respules $^{\mathrm{TM}}(0.5 \mathrm{mg})$ & 8.70 & 3.38 & $5-16$ \\
\hline Nanobudesonide $(0.5 \mathrm{mg})$ & 7.06 & 3.11 & $5-16$ \\
\hline Nanobudesonide $(1.0 \mathrm{mg})$ & 6.95 & 2.48 & $4-13$ \\
\hline
\end{tabular}


Figure. Time course of mean budesonide concentrations in plasma following oral administration of nanocrystal budesonide $0.5 \mathrm{mg}$ (circles), nanocrystal budesonide $1.0 \mathrm{mg}$ (squares), and Pulmicort ${ }^{\circledR}$ Respules $^{\mathrm{TM}} 0.5 \mathrm{mg}(+)$.

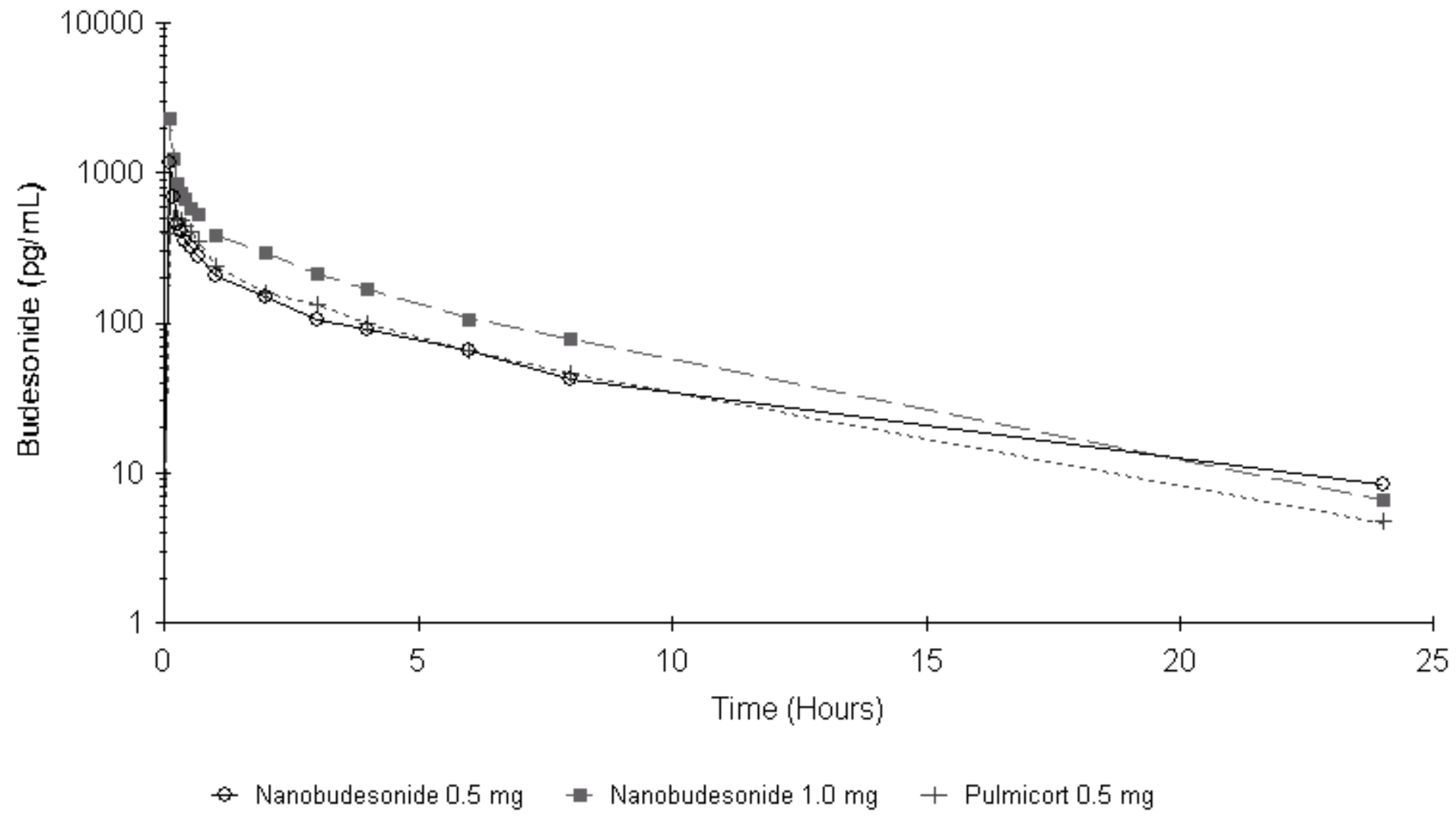




\section{References}

${ }^{1}$ Leach CL. Improved delivery of inhaled steroids to the large and small airways. Respir Med. 1998;92(Supplement):3-8

${ }^{2}$ National Asthma Education and Prevention Program Expert Panel Report 2: Guidelines for the Diagnosis and Management of Asthma. NIH Publication No. 97-4051

${ }^{3}$ Haahtela T., Jarvinen M, Kava T, Kiviranta K, Koskinen S, Lehtonen K, et al. Comparison of a beta 2-agonist, terbutaline, with an inhaled corticosteroid, budesonide, in newly detected asthma. N Engl J Med. 1991; 325:388-39.

${ }^{4}$ Haahtela,T, Jarvinen M, Kava T, Kiviranta K, Koskinen S, Lehtonen K. et. al. Effects of Reducing or Discontinuing Inhaled Budesonide in Patients with Mild Asthma. N Engl J Med. 1994;331: 700-705

${ }^{5}$ Fish JE, Peters SP. Airway remodeling and persistent airway obstruction in asthma. J Allergy Clin Immunol. 1999;104(3 Pt 1):509-16

${ }^{6}$ Miller-Larsson H, Mattsson H, Hjertberg E, Dahlbeck M. Tunek A, Zand Bratsand R. Reversible fatty acid conjugation of budesonide. Novel mechanism for prolonged retention of topically applied steroid in airway tissue. Drug Metab Disp. 1998;26(7):62330

${ }^{7}$ Keller M, Jauernig J, Lintz FC, Knoch M. Nebulizer nanosuspensions: Important device and formulation interactions. Respiratory Drug Delivery VIII, The Aerosol Society (Eds.), May 2002, 197-206 
${ }^{8}$ de Blic J, Delacourt C, Le Bourgeois M, et al. Efficacy of nebulized budesonide in treatment of severe infantile asthma: double-blind study. J Allergy Clin Immunol. $1996 ; 98: 14-20$

${ }^{9}$ Grimfeld A, Lesbros D, Ostinelli J, Caswell C. Long-term study of nebulised budesonide in young children with moderate to severe asthma [abstr]. Eur Respir J. 1994;7(Supplement 18):27S

${ }^{10}$ Wennergren G, Nordvall SL, Hedlin G. Moller C, Wille S, Asbrink Milson E. Nebulized budesonide for the treatment of moderate to severe asthma in infants and toddlers. Acta Paediatr. 1996;85:183-9

${ }^{11}$ Ilangovan P, Pedersen S, Godfrey S, Nikander K, Noviski N, Warner JO. Treatment of severe steroid dependent preschool asthma with nebulized budesonide suspension. Arch Dis Child. 1993;68:356-59

${ }^{12}$ Toogood JH, Frankish CW, Jennings BH, Baskerville JC, Borga O, Lefcoe NM, Johansson SA. A study of the mechanism of the antiasthmatic action of inhaled budesonide. J Allergy Clin Immunol. 1990;80:241-247

${ }^{13}$ Agertoft L, Pedersen S. Effect of long-term treatment with inhaled budesonide on adult height in children with asthma. N Engl J Med. 2000;343:1064-1069

${ }^{14}$ Wolthers OD; Pedersen S. Growth of asthmatic children during treatment with budesonide: a double blind trial. BMJ. 1991;303(6795):163-5 
15 Szefler SJ. A review of budesonide inhalation suspension in the treatment of pediatric asthma. Pharmacotherapy. 2001;21(2):195-206

${ }^{16}$ Andersson P, Ryrfeldt A. Biotransformation of the topical glucocorticoids, budesonide and beclomethasone, 17,21-dipropionate in human liver and lung homogenate. J Pharm Pharmacolol. 1984;36:763-765

${ }^{17}$ Donnelly R, Seale JP. Clinical Pharmacokinetics of inhaled budesonide. Clin Pharmacokin. 2001;40(6);427-439

${ }^{18}$ Lipworth BJ. Pharmacokinetics of inhaled drugs. Br J Clin Pharmacol. 1996;42:697705

${ }^{19}$ Onhoj J, Thorsson L, Bisgaard H. Lung deposition of inhaled drugs increases with age. Am J Respir Crit Care Med. 2000;162(5):1819-22,

${ }^{20}$ Ageroft L, Anderson A, Weibull E. Pedersen S. Systemic availability and pharmacokinetics of nebulized budesonide in preschool children. Arch Dis Child. $1999 ; 80: 241-7$

${ }^{21}$ Szefler,S. Pharmacodynamics and pharmacokinetics of budesonide: A new nebulized corticoid steroid. J Allergy Clin Immunol. 1999;104;4 Part 2: S175-182

${ }^{22}$ Tashkin,DP. HFA-BDP and its implications for the quiet zone. Respir Med. 2000; 94 Supplement. D:S37-39

${ }^{23}$ Lim KG. Management of persistent symptoms in patients with asthma. Mayo Clin Proc. 2002;77:1333-1339 
${ }^{24}$ Wildhaber JH, Devadason SG, Wilson JM, Roller C, Lagana T, Borgstrom L, LeSouef PN. Lung deposition of budesonide from turbuhaler in asthmatic children. Eur J Pediatr. $1998 ; 157(12): 1017-22$

${ }^{25}$ Harrison TW. Systemic availability of inhaled budesonide and fluticasone propionate: healthy versus asthmatic lungs. Biodrugs. 2001;15(6):405-11,

${ }^{26}$ Kim CS, Hu SC. Regional deposition of inhaled particles in human lungs: comparison between men and women. J Appl Physiol. 1998;84(6):1834-44 